\title{
Resenting Byzantine Iconoclasm. Its Early Reception in Italy through an Inscription from Corteolona
}

\author{
Francesca Dell'Acqua and Clemens Gantner*
}

A source which can be dated to $c .730$ has never been discussed as evidence of an early reception of Byzantine iconoclasm in Italy. Now lost, this was an inscription put up to celebrate the foundation of a church in the newly established royal residence of the Lombard king Liutprand (712-744) in the countryside of Pavia along the river Olona, known as Corteolona. The inscription tells us that in the time in which >Caesar Leo fell into the pit of schism from the summit of righteousness persuaded by a miserable scholars, Liutprand dedicated a church to Saint Anastasius the Persian. Therefore, the inscription makes use of the perceived heterodoxy of the Byzantine ruler - his attitude towards sacred images - as a chronological and negative cultural reference. In the inscription, Liutprand is cast as a champion of the Catholic Church as opposed to the heterodox Leo III (717-741). This claim naturally had wider political implications: Liutprand wanted to be seen as the supreme ruler on the Italian peninsula. The inscription from Corteolona, with others from Pavia and its surroundings, was transcribed in the late eighth century and thus transmitted to posterity. Having often escaped the attention of those interested in the echoes of Byzantine iconoclasm outside Byzantium, its text is an important document since it suggests that in early eighth-century Lombard Italy, at least in some circles, it was believed that Emperor Leo III was acting against orthodoxy, and that this could potentially lead to a schism within the Catholic Church. In the same years, the early 730s, the papacy too reacted to rumours of heterodoxy in the east, specifically in Constantinople: both a letter by Pope Gregory III (731-741) and the Roman Liber Pontificalis attest to this.

Keywords: Byzantine iconoclasm, Liutprand (King of the Lombards), Corteolona, Saint Anastasius the Persian, Emperor Leo III, Paul the Deacon, Sylloge Laureshamensis, Lombard Italy, Papacy

* Correspondence details: Dr. Francesca Dell'Acqua, Dipartimento di Scienze del Patrimonio Culturale, Università degli Studi di Salerno, Via Giovanni Paolo II, 84084, Fisciano (Salerno), Italy, fdellacqua@unisa.it.

Dr. Clemens Gantner, Institut für Mittelalterforschung, Österreichische Akademie der Wissenschaften, Hollandstraße 11-13, 3. Stock, 1020 Wien, Österreich, clemens.gantner@oeaw.ac.at.

Though the contribution has truly been a collaborative effort, each author was responsible for particular sections: Francesca Dell'Acqua wrote the chapters on Saint'Anastasius the Persian and on the material appropriation of Rome in Italy, plus has generally been responsible for questions of material culture and inscriptions, as well as Liutprand's laws, whereas Clemens Gantner was responsible for the papal sources connected with the topic, political history between the Lombards, popes and Byzantium and the question of the alleged instigator of iconoclasm. The introduction, conclusion and the central chapter on the text of the Corteolona inscription and the Lorsch manuscript containing it can only be assigned to both. 


\section{Introduction}

This paper discusses a lost inscription originally set up in the church or in the monastery of Saint Anastasius the Persian annexed to Corteolona, a new residence the Lombard king Liutprand (712-744) established in the countryside of Pavia along the river Olona in the late 720s-early 730s. Known to scholars of Lombard Italy, the inscription has indeed been mentioned by researchers dealing either with the image of Liutprand as sovereign or with Lombard literacy. ${ }^{1}$ But despite offering an interesting and rare witness to an early reception of Byzantine iconoclasm (or controversy on sacred images) in Italy, it is absent even in thorough overviews of the subject. ${ }^{2}$ Here we intend to focus on what the inscription transmits about Byzantine iconoclasm and, at the same time, comment on its wider implications for the cultural and political history of the reign of Liutprand. The question of the transmission of the inscription, which is an intriguing issue, will also be addressed in this paper.

\section{The inscription - text and translation}

The following are the transcription and the translation of the first and the third inscriptions from Corteolona preserved in the Sylloge Laureshamensis (Rome, BAV, Pal. lat. 833), to which we shall return later. The first text reads:

Ecce domus domini perpulchro condita textu emicat et vario fulget distincta metallo.

Marmora cui pretiosa dedit museumque columnas

Roma caput fidei, illustrant quam lumina mundi.

Euge auctor sacri princeps Leutprando [sic!] laboris, te tua felicem camabunt acta per aevum qui proprie gentis cupiens orare triumphos his tituilis patriam signasti denique tot[a]m. ${ }^{3}$

Behold the house of the Lord, built with beautiful materials, it shines forth and glistens, decorated with various metals. Rome, the capital of the faith, has given it its precious marble, mosaics and columns - oh how these give light to the eyes of the world! Rejoice for Prince Liutprand, the author of this holy work! Your deeds will proclaim you fortunate throughout time, you, who, desiring to decorate the triumphs of your people, have stamped the whole country with these inscriptions. ${ }^{4}$

On the inscription, see Calderini, Il palazzo di Liutprando, 179-180; Badini, Concezione della regalità; Everett, Literacy, 248-250 (who does not discuss the figure of the mentioned emperor or the philosopher or which schism it was); Vircillo Franklin, Latin Dossier, 16-18; Lopez-Jantzen, Kings of all Italy?; Lauxtermann, Lombard epigram.

2 It has apparently escaped the attention of Noble, Images; and Brubaker and Haldon, Byzantium: A History, see ibid. 79-127.

3 BAV Pal. Lat. 833, fol. 48v. Emended in current editions.

4 Translation by Everett, Literacy, 248-250, adapted by the authors. 
The third inscription from Corteolona is the most relevant to the present study:

Quando Leo cecidit, misero Doctore suasus, scismatis in foveam recto de culmine Caesar, tunc ego regales statui his mihi condere thermas marmoribus pulchris Leutbrant Rex atque columnis.

Sed Romam properans postquam devotus ad ipsam perveni atque sacro capiti mea basia fixi Sancti Anastasii, servus tuus, ecce repente paterna de sede meo hanc in pectore, Christe, praeclaram fundare domum sub culmine monstras. Talibus unde meas tendens ad sidera palmas vocibus oro: 'Dei Fili, pro plebe fideli, Qui regis angelicos coetus, qui cuncta gubernas, Fac, precor, ut crescat mecum catholicus ordo, et templo concede isti ut Salomoni locutus. ${ }^{5}$

At the time Caesar Leo [the emperor] fell into the pit of schism from the summit of righteousness persuaded by a miserable scholar, I, King Liutprand decided to have baths built for myself, using these beautiful marble columns. But later I hastened, as a devoted man, to Rome herself - when I arrived there, as your [Christ's] servant, I kissed the holy head of Saint Anastasius. And see, all of a sudden, you, Christ, show me in my bosom from your heavenly seat that I am to donate this magnificent house [church] under the roof [of the palace]. Hence, elevating my hands towards the stars, I pray with these words: 'Oh son of God, for the faithful people, you, who leads the host of angels, you, who reigns over everything, I beg you, to make the Catholic community grow with me and support this temple, as was promised to Solomon< ${ }^{6}$

\section{The chronological context and the question of sacred images}

Those above are the two main inscriptions transmitted from Corteolona. ${ }^{7}$ They relate to many questions whose full analysis exceeds the scope of the present paper. We must focus on a selection of them, foremost among which is the reference to the Byzantine emperor seen as sschismatic . Let us first consider the chronological context of this unprecedented declaration.

The longer inscription under study ('Quando Leo cecidit`) claims that Liutprand had already established his residence at Corteolona by the time he went to Rome on a pilgrimage as a devout man. This spiritual experience evidently resolved him to abandon the idea of using Roman marble and columns to build baths and build instead a church. It should be stated clearly that there is no precise historical or archaeological data about the foundation of the residence of Corteolona nor of the church of Saint Anastasius the Persian. The area of the former Lombard court is under a working farm and has not been investigated by archaeologists. ${ }^{8}$ We are left with only the chronological hint to the establishment of the church of Saint Anastasius in the inscription that Liutprand commissioned after his visit to Rome.

5 Versus xii, In Ecclesia Beati Anastasi, ed. Dümmler, 106.

6 Translation by the authors, using Everett, Literacy.

7 There is a third inscription recorded, second in the manuscript. It is only two lines long and in hexameter, see BAV Pal. Lat. 833 , fol. $48 \mathrm{v}$.

8 See Calderini, Il palazzo di Liutprando. The authors were unable to consult Riccardi, Le vicende. 
The king arrived outside Rome twice during his tenure, on both occasions actually threatening the city and the pope. But he entered Rome only once, in 729. He was invited after prolonged negotiations, which led to a compromise between the Lombard kingdom, and its ally, the Byzantine exarch of Ravenna on the one side and the papacy, and its allies, the Lombard dukes of Spoleto and Benevento on the other side. Liutprand is said to have put down his coat at St Peter's confession as a devout gesture on this occasion..$^{9}$ Ottorino Bertolini linked the occasion of Liutprand's first visit in 729 to the establishment of the church at Corteolona. ${ }^{10}$ Carmela Vircillo Franklin instead favours a later date for the establishment of the church, connected to Liutprand's second visit to Rome in $739 .{ }^{11}$ We will see why the first date, c.729, is the most likely for the Roman pilgrimage mentioned and, at the same time, a terminus post quem for the dedication of the church and for the inscription. It is very likely that both happened between 729 and the early 730 s.

In order to understand what happened, we need to give a short introduction to the communication and conflict-triangle of the Lombards, the papacy, and the Byzantines in the early eighth century. The second half of the 720 s was a difficult time for Italy: Emperor Leo III, in reaction to continuous problems with the Umayyad caliphate in the east, raised taxes in the Italian provinces. With no significant military help coming from the east, these had been under pressure from the Lombard kingdom and the semi-independent duchies of Spoleto and Benevento for quite some time, and hence were disinclined to obey their eastern overlords. The result was what has rightfully been called a stax war between Rome and the Exarchate of Ravenna, which had been entrusted with executing the emperor's orders. Our best source on these events, the Roman Liber Pontificalis, that is the papacy's semi-official chronicle, gives a detailed account of these circumstances, although with an important alteration, as we shall see. ${ }^{12}$ At first, the Lombards helped defend Rome and Pope Gregory II (715-731) against the army of Ravenna. Note that at this point our source does not distinguish between the different Lombard powers. Soon thereafter, probably in 727, we are informed that the exarch had allied himself with Liutprand, king of the Lombards since 712. Both threatened Rome, but Liutprand soon broke off the military engagements and started to negotiate a peace agreement, the exact terms of which we do not know. Thomas Noble is probably spot on with his interpretation that Liutprand wanted to break the existing alliance between the southern Lombard duchies and the papacy, and the peace treaty seems to have resulted in just that. We do not know what the agreement with the exarch Eutychius which must have been reached during the same negotiations entailed, but we do know that in this case, too, a feeble accord was the outcome. ${ }^{13}$ Matters were, however, even more complicated. During the tax controversy, the countryside to the north of Rome, called Roman Tuscany at the time, had been in outright insurrection. The rebels supported an imperial pretender, called Tiberius Petasius.

10 Bertolini, Roma e i Longobardi, 38-42. This date is accepted by Badini, Concezione della regalità, 290-291, 299; Everett, Literacy, 248; Lopez-Jantzen, Kings of all Italy?, 85. See also: Berto, Liutprando, re dei Longobardi. Vircillo Franklin, Latin Dossier, 16, follows Giorgi, Il Regesto del monastero di S. Anastasio ad Aquas Salvias, 53. 
Maybe it was Pope Gregory II taking a firm stance against this usurpation that got him a deal with Byzantine representatives. The latter, at an earlier point in the conflict, had even plotted the assassination of the pope, as the Liber Pontificalis also informs us, so the relations must have been rather strained. ${ }^{14}$ Certainly Liutprand withdrawing the support of the largest army on the peninsula would have further induced the exarch to come to terms.

To this already complex narrative, the Liber Pontificalis added another major ingredient: it claimed that all the quarrels, which the text itself never styles as a war, resulted from the emperor wishing to impose a ban on images in the Italian province. An attempt to arrest and kill the pope is explained thusly: >A few days later the emperor's wickedness that made him persecute the pontiff became clear: to force his way on everyone living in Constantinople by both compulsion and persuasion to take down the images, wherever they were, of the Saviour, his holy mother and all the saints, and, what is painful to mention, to burn them in the middle of the city $<.{ }^{15}$

The entry for Gregory II was, with quite some certainty, started when the pope was still alive, but it was finished at the time of his successor Gregory III (731-741). Another, revised version of the Life of Gregory II was produced later, probably under Pope Zachary (741-752). Iconoclasm, or rather, more fitting to the worldview of the Liber Pontificalis, the image controversy, is present in both versions. Bede, active at the monastery of Jarrow in Northumbria used the older version of Gregory II's Life by the mid-730s at the very latest, as he died in 735, indicating that a first version of the Life was already circulating in the early 730 s. $^{16}$ Whether or not the attribution of spurring iconoclasm to Leo III was already part of this text-version cannot be proven, but it is very likely that some information tending in that direction was indeed part of it from an early date, and was certainly included when the earlier version of the Life was finished during the pontificate of Gregory III.

Liutprand visited Rome soon after he had concluded his negotiations with the papacy and restored to their property the castellum of Sutri, which he had seized in 728 , to Pope Gregory II. ${ }^{17}$ The sovereign wished to reconcile with the papacy, while he was keen to display his position as the supreme secular ruler of the peninsula. His attacks against the Byzantine Exarchate in 727 have been read in this light. ${ }^{18}$ We should pay attention to the fact that laws Liutprand promulgated in the late 720 s further manifest his intention to underline his status as supreme, orthodox, benign ruler of the whole Italian peninsula. ${ }^{19}$ Promulgating laws and displaying public inscriptions was a way of promoting the image of a ruler - undoubtedly, there remains a question of audience, since literacy was the prerogative of few, but laws were made for all. ${ }^{20}$

Gantner, Freunde Roms, 26-27, with n. 57: the terminus ante quem for this text is 735, but we do not know whether a full version reached Bede in northern England.

17 LP, Gregory II, c. 21, ed. Duchesne, vol. 1407.

18 Lopez-Jantzen, Kings of all Italy?, 85.

19 Badini, Concezione della regalità, 297, who bases his interpretation on Bertolini and Violante, Germani, 274; Everett, Literacy, 251; Lopez-Jantzen, Kings of all Italy?, 85. See also Pohl, Legal pluralism. At the conference >Liutprando re dei longobardi< (May 2018), Germana Gandino delivered a paper about Liutprand and his idea of sovereignty as projected by his laws which has not been published yet.

20 Everett, Literacy, is dedicated to this aspect in Lombard Italy before the conquest of Charlemagne. 
All the same, it is worth reporting a couple of excerpts where Liutprand speaks in the first person in a tone that seems echoed by the Corteolona inscription, despite the latter being more emphatic. This is what Liutprand says in the prologue to his laws of 727 :

We have taken care to add those provisions which we believed to be pleasing to God and to good men ... First of all, in defence of our Christian and Catholic law we make provision that no one may presume to wander from the faith of Christ, that we may have God as a defender and helper firmly and permanently in all things. ${ }^{21}$

And this is what he proclaims in 728 :

We have added to the ancient lawbook those laws which we regarded as beneficial to our soul and contributing to the salvation of our nation. We now in a like manner with divine aid in order that perjury may not occur nor quarrels arise among our faithful people [fideles], acting together with our judges and with the Lombard faithful people, add [these laws] on this first day of March in the sixteenth year of our reign, Christ protecting, in the eleventh indiction: we call upon God as our witness [that we do this] not for any vain glory or human praise but to please almighty God and remove our subjects from error. ${ }^{22}$

As said, the dating of the Corteolona inscription is closely related to the king's pilgrimage to the relic of Anastasius the Persian in Rome. A date for the pilgrimage - and for the inscription - in the late 730 s is not supported by the historical circumstances. While we have no clear indications about the developments of Byzantine iconoclasm in these years, ${ }^{23}$ the political scenario in Italy was changing. After 735 Liutprand did not issue laws and his voice is not heard as it was in the previous decade. Apparently in c.734, before or after the siege he laid to Ravenna, the king was afflicted by an illness that impaired him to the point that Lombard aristocrats delegated his power to his nephew Hildebrand. ${ }^{24}$ By 739 , however, Liutprand, evidently in better health, was campaigning against Rome and in the same year he joined forces with his nephew against the Byzantine Pentapolis. ${ }^{25}$ Therefore, Liutprand's second journey to Rome was no devout pilgrimage. He would only come to better terms with the pope in 742. In the meantime, the papacy had restored its good relations with the Byzantine Empire, because now the Lombard

21 Laws of Liutprand, ed. Pertz, 141: IIam enim vicibus illa in antico edicti corpore aucmentare previdemus, quae credimus deo et bonis hominibus placita esse .... Primum omnium statuere previdemus pro christianae et catholicae legis defensione, quatinus nullus a fide Christi oberrare presumat, sed firmiter in ea permanentis deum possemus habere defensorem atque propitium‘; English trans. Fischer Drew, Lombard Laws, 180.

22 Laws of Liutprand, ed. Pertz, 146-147: >Pluribus iam quidem vicibus in antiquo edicti corpore ea adiungere curavimus quae pro salute animae et gentis nostrae salvatione esse prospeximus; nunc itaque simili modo ea considerantes, quae secundum deum recta esse cognovimus, ut nec periura nec iurgia inter nostros emergantur fideles, una cum nostris iudicibus atque fidelibus langobardis, et modo presenti tempore die kalendarum martiarum anno Christo protegente regni nostri XVI, indictione XI, iterum adiungere, deum invocamus testem, non pro aliqua vana gloria aut laude humana querendum, sed dei omnipotenti placendo et nostros de errore tollendo subiectos<; English trans. Fischer Drew, Lombard Laws, 185-186.

23 Brubaker and Haldon, Byzantium: A History, 79-89.

24 Paul the Deacon, HL, vi, 55, ed. Waitz, 184.

25 At the conference 'Liutprando re dei longobardi< (May 2018), Claudio Azzara delivered a paper about Liutprand and his relationship with the popes which has not been published yet. 
king was the common enemy. ${ }^{26}$ Walter Pohl has pointed to the fact that all historiography we have on these events aims at construing an antagonism between the Lombards and the papacy, with the former clearly in the role of the aggressor. Not even Paul the Deacon, the author of the History of the Lombards, escapes this black and white scheme, because his main source for this period was the Liber Pontificalis. ${ }^{27}$ Unsurprisingly then, the preserved sources, be they of papal, Frankish or even Lombard origin, do not show Liutprand in a favourable light at this point, certainly not as the pious, benign, and orthodox ruler he was promoting himself as ten years earlier and as which he emerges from the longer Corteolona inscription.

We should remark that the inscription does not mention a specific theological controversy when noting that Emperor Leo had fallen into the pit of schism, with this implying that his actions could lead to a schism within the Catholic Church. ${ }^{28}$ But the only theological controversy which Leo III is associated with is that concerning sacred images. There is no proof that Leo issued an edict against sacred images in 726 or that he ordered the destruction of an image of Christ on the main door of his Constantinopolitan palace, as later historiography maintained. ${ }^{29}$ What the controversy about sacred images really was at first is not clear, and nor was it to its contemporaries. Its origins as well as its traits in the 720 s remain blurred despite an abundant scholarly production about it. As Leslie Brubaker and John Haldon have noted, 'while we will never know what exactly was known in Rome about what was happening in Constantinople, it seems clear that something to do with images, which was construed in some way as a threat, had attracted comment, in Rome at least.${ }^{30}$ The inscription tells us that this controversy, blurred as it seemed in the West, had nonetheless attracted comments at the Lombard court. The chosen expression sschism ‘ clearly signals that such a danger within the Catholic Church was truly feared as the consequence of Leo's unorthodox behaviour. In northern Italy, the events of the Three Chapter Controversy, which had put the episcopal sees there into opposition with nearly all centres of the empire, eventually also including Rome, were surely still in the back of everyone's mind. After all, communion in the Church had only been restored at the synod of Aquileia in $698 .{ }^{31} \mathrm{~A}$ split opinion and division within ecclesiastical ranks is also what the Constantinopolitan patriarch Germanos feared and expressed in a letter he wrote to a bishop between 720 and 730 , which is only known through the acts of the iconophile Council of Nicaea II (787)..$^{32}$ That contesting sacred images could lead to divisions in the Church is confirmed decades later by the sacra, or opening letter, addressed by emperors Irene and Constantine VI to the bishops convened at the Council of Nicaea II: it insists on the importance of ecclesiastical speace and concord.$^{33}$

26 Brubaker and Haldon, Byzantium: A History, 89, support the idea that the relations between the papacy and the empire had been tainted by fiscal and not doctrinal questions in the 720 s and early 730 s.

27 Pohl, Das Papsttum und die Langobarden.

28 Vircillo Franklin, Latin Dossier, 17, with no hesitation writes that the orthodoxy of Liutprand is contrasted 'with the heresy of the Byzantine ruler Leo (III Isauricus), the supporter of iconoclasm،.

29 For an appraisal of the evidence, see Brubaker and Haldon, Byzantium: A History, 119-135.

30 Brubaker and Haldon, Byzantium: A History, 86.

31 On the Three Chapter controversy see Sotinel, Dilemma des Westens.

32 Mansi, XIII, 105B-E; ACO II, 3.2, ed. Lamberz, 450-453; Brubaker and Haldon, Byzantium: A History, 94-98, and 101 on schism.

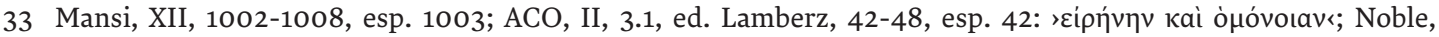
Images, 77-78. 
Who was the miserable scholar?

The longer inscription from Corteolona mentions a miserable scholar ('misero doctore ‘) who is to be blamed for having misguided Leo into the pit of schism. There is no hint as to whose was this learned but perverted mind, which had brought the emperor under the yoke of heresy. In the acts of Nicaea II, a priest recalls a story in which a Jewish soothsayer, named Tessarakontapechys or also Sarantapechys, the Caliph Yazid, and Leo feature simultaneously. The Jewish soothsayer (Hebraios) convinces the caliph to persecute Christians and also indirectly has an influence on Leo's actions against sacred images. Scholars maintain that this is the first secure reference to an alleged Islamic or Jewish influence on Leo's iconoclasm. ${ }^{34}$ Our inscription alludes to the influence of a bad advisor on the emperor already by $c .730$, without giving further information on that man's ethnic or religious background. It is possible that the Corteolona text is a very early witness to the legend of the bad advice in the making.

An alternative would be that the author of the inscription meant one of the several theologians who were involved in the development of a new doctrine of sacred images at that very time. These could have been collectively addressed with the smiserable doctor of the inscription. In the Latin of the eighth century, the term doctor was often used for theologians or religious scholars. For instance, Saint Augustine is frequently labelled as such. Therefore, we should ask who was meant by this expression. We know that Patriarch Germanos of Constantinople had been replaced by Anastasios, possibly his former pupil, in January 730. It is still impossible to say whether the inscription is actually referring to Anastasios, as next to nothing is known about the latter's theological position early in the conflict. Anastasios' defection to the iconophile usurper Artabastos between 741 and 744, accompanied by support for the iconodules at that time may indicate that he was neither a big ideologue nor the main instigator of a doctrine against images..$^{35}$ Other theologians are very prominent in later texts about iconoclasm, for example Bishop Constantine of Nakoleia. ${ }^{36}$ The problem here is that it is far from likely that these scholars could be implicated in having influenced the emperor directly, having no tangible connection to the court.

The connection between Emperor Leo and bad advisors was obviously made quite casually in later decades. This is proven by the synodical letter Pope Hadrian I sent shortly before the Second Council of Nicaea, included in the acts of the council. ${ }^{37}$ Considering our scarce information, we have to admit that we are unable to pinpoint who the smiserable scholar was. But this is not the point here either. There were indeed several candidates, who could

34 Mansi, XIII, 197B-20oB; ACO II, 3.2, ed. Lamberz, 590-595 (Actio V). See Speck, Ich bin's nicht, on the developments of this legend, that involved at one point also Leo III's son Constantine V; Brubaker and Haldon, Byzantium: A History, 116. Speck has argued, sometimes in a formulaic way, for a later date of documents related to Byzantine iconoclasm on the assumption that in the late eighth century iconophiles forged documents or interpolated them in order to exaggerate the iconoclasts « wrongs and essentially re-write the history of eighth-century Byzantium.

35 PmbZ, no. 285, Anastasios (Eirenaios), retrieved on 19 Feb. 2019: www.degruyter.com/view/PMBZ/PMBZ11367.

36 See Brubaker and Haldon, Byzantium: The Sources, 94-105 for these theologians. On Constantine see: PmbZ, no. 3779, Konstantinos, retrieved on 19 Feb. 2019: www.degruyter.com/view/PMBZ/PMBZ14929.

37 Mansi XII, 1060D-1061B; ACO II, 3.1, ed. Lamberz, 127: ^Sed ipse vester proauus per quorundam impiorum immissiones easdem deposuit sacras imagines, et ex hoc error magnus in ipsius Greciae partibus accrevit et ingens scandalum in universum evenit mundum. Hadrian's letter was included in an abridged version, excluding information unfavourable for the Byzantine Empire, see Lamberz, Falsata Graecorum more?. 
be implicated in this early stage of anti-image policy. It is very likely that one of these protagonists - or even a personal advisor to the emperor - was meant here. The most interesting feature of this part of the text is that the smiserable doctor/scholar clearly takes some of the blame away from Emperor Leo. In the eyes of a medieval onlooker, however, that would not have been enough: a good, God-loving emperor would also choose the right advisors, thereby preventing himself getting into this situation. In the inscription, Liutprand, who speaks to us in the first person, acknowledges that a ruler can indeed be misled by the experts he employs as advisors - only to emerge himself as a wise and orthodox ruler.

\section{The pious sovereign and the Persian martyr}

The Corteolona inscription casts Leo III as a schismatic, that is, as a heterodox ruler. As a matter of fact, for some years Leo III enjoyed the role of champion of the faith in having defended Constantinople from the Arab siege of 717 and having put an end to the monothelete revival of Philippikos Bardanes. His achievements as a practical and effective sovereign have been remarked by scholars reversing the bad image which iconophile sources of the late eighth century drew of him..$^{38}$ But although the role Leo had in the early stages of the iconoclastic controversy remains unclear, he must have at the very least tolerated the iconoclast argument and activities`, as noted by Brubaker and Haldon. ${ }^{39}$ Therefore, if we accept a date for the Corteolona inscription around 730, we have to conclude that Leo III must have gained a bad reputation in association with iconoclasm long before the late eighth century. We should also remark that the target of the Corteolona inscription is not Leo's active stance in favour of a potentially schismatic religious policy, but rather his lack of firmness against it (through the reference to a miserable scholar), and his negligence as sovereign and custodian of values, including religious orthodoxy.

We should now consider for which purpose the Corteolona inscriptions intended to exploit the (supposed) bad name of the Byzantine emperor. Liutprand and his advisors must have sensed that something 'wrong w was going on in the Eastern Church and that it could threaten the unity of Christendom as a whole. How they became aware of these unfolding and still quite obscure events relating to Leo's misconduct remains conjectural, although there were several persons or institutions in Italy that were apparently well informed, including the pope. It remains the case that they were quick to understand that these circumstances could turn into an opportunity. With Leo III in schism, Liutprand could rise to the role of the main protector of the Church headed by Rome, and potentially acquire the influence and prestige associated with the Byzantine emperor, the supreme ruler in the Christian world. ${ }^{40}$ In the Corteolona inscriptions, Liutprand clearly embraces this opportunity. In line with his predecessors who, after abandoning Arianism became integrated in the Catholic Church, ${ }^{41}$ and against the hetherodox Byzantine emperor Leo, Liutprand wishes to be seen

38 Brubaker and Haldon, Byzantium: A History, 69-155, evaluate a vast body of evidence.

39 Brubaker and Haldon, Byzantium: A History, 140.

40 See Gantner, Label Greeks.

41 After Aripert I (d. 661), Lombard kings abandoned Arianism. Paul the Deacon portrays them as pious rulers, see for example Perctarit (d. 688), HL, V, 33, ed. Dümmler, 155; Hallenbeck, Pavia and Rome, 15. See Cornford, Paul the Deacon, 52, on Paul the Deacon's 'willingness to incorporate himself into a Latin and Catholic identity<. 
as the true defender of the Catholic faith. He appears as a self-styled champion of orthodox faith: praying with his palms upward, he wholeheartedly invokes the help of the Son of God to make the Catholic faith grow with him. Rome is addressed as sthe capital of the faith', to which the sovereign had hastened in pilgrimage. Embracing Rome with its political and religious legacy had vast implications. The supremacy of Rome in the Christian oecumene had been recognised at the Sixth Ecumenical Council held in Constantinople in 680-681 and was ratified by the Byzantine emperor Constantine IV..$^{42}$ As Benjamin Cornford has epitomised, >The strength of the Roman-Christian discourse was such that the equation of this civilised ideal of Catholic Romanitas with the imperial idea of universality retained a clear potency in the eighth century ${ }^{4}{ }^{43}$

The final line of the longer inscription mentions King Solomon and his temple. Solomon and Emperor Justinian, who erected the Hagia Sophia in Constantinople, would be recalled by Paul the Deacon in verses praising the Duke of Benevento Arichis II, ${ }^{44}$ who had taken the reins of the Lombard people after Charlemagne's conquest of Langobardia Maior. Aldo Badini has remarked that in the case of Liutprand, Solomon offered an important role model not only because he built a temple to the Lord. Solomon represented the idea of a legitimate sovereign, of the kind Liutprand aimed at being recognised as since his power had been contested by some Lombards. ${ }^{45}$ Finally, Solomon represented the idea of a sovereign entitled to mediate between his subjects and God and therefore to control and coordinate the ecclesiastical organisation (1 Kings 2, 26-27).

We should now turn back to the question of Liutprand's establishment of a church dedicated to Anastasius the Persian. As mentioned, Liutprand visited the monastery of Saint Anastasius ad aquas salvias, not far from St. Paul outside the walls. ${ }^{46}$ This in all probability happened when he first went to Rome, in 729. The longer Corteolona inscription says that he paid his respect to the saint by kissing his head. Only a few years earlier, in 713, the head of Anastasius had performed a miracle in Rome which was recorded in Greek immediately afterwards, likely

42 Letter from the theologians convened at the council to Pope Agatho, in the Acts of the Sixth Ecumenical Council,

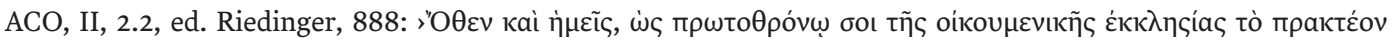

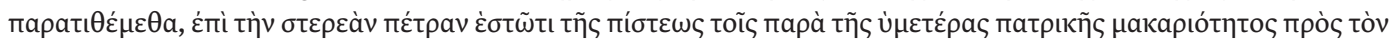

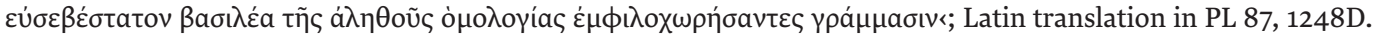

43 Cornford, Paul the Deacon, 60.

44 Paul the Deacon, Versus de Arichi duce, VII, 4-5, ed. Dümmler, MGH, PLAK 1, 45: `Regnator tibi summe decus trinominis ille / Hebreae gentis Solymis construxit asylumr. On Paul the Deacon's praise of Justinian as an ideal model for rulership, see HL, I, 25, ed. Dümmler, 62; Pohl, Creating cultural resources, 28. On Solomon, Justinian, and Arichis, see Everett, Literacy, 250; Falla Castelfranchi, Arechi II e Giustiniano, 83; Dell'Acqua, Arechi II, 80-81, 83-84. Paul the Deacon also extolled Arichis as ıcatholicus princeps‘, see Versus de Arichi duce, VI, 13, ed. Dümmler, 44.

45 Badini, Concezione della regalità, 292-296.

46 On Liutprand and the monastery of S. Anastasius ad aquas salvias, see Fentress et al., The Sixth-Century Settlement, 90-91. 
at the monastery of Saint Anastasius ad aquas salvias. The daughter of a Syrian bishop living in Rome had been delivered from an evil spirit thanks to the intervention of the precious relic, confirming the bishop, who had refused recourse to an amulet, in his orthopraxis. ${ }^{47}$ The agency of holy heads seems to be the focus of the miracle account, which underlines the fact that the monastery ad aquas salvias was the place where the apostle Paul was beheaded, and where the head of Anastasius was hosted. In its vicinity there was a chapel in memory of John the Baptist, who was beheaded, and where the miracle ultimately takes place. While we cannot advance the claim that accounts of miracles performed by the relics of Anastasius attracted the attention of Liutprand, it is a fact that in the early decades of the eighth century his relics, and his head in particular, were the object of popular devotion in Rome.

Once back in Langobardia after his visit to the monastery of Saint Anastasius ad aquas salvias, Liutprand decided to invest precious materials he had gathered for his baths in building a church in memory of the Persian martyr annexed to his new palatial complex. Building baths, which entailed using a specialised workforce and precious materials, had been a prerogative of the rich and powerful in Antiquity. In the early medieval period the public bath culture had declined, apparently more for economic reasons than as a result of Christian criticism, and had only survived, albeit strictly regulated, in Byzantine monastic establishments and in luxury private estates. ${ }^{48}$ Unusually for early medieval Italy, in the early eighth century a bishop of Pavia, probably of Greek origin, restored the local baths, as we know from his epitaph, which is transcribed in the Sylloge Laureshamensis. ${ }^{49}$ Badini suggested that, after having been to Rome to reconcile with the pope in 729, Liutprand abandoned the idea of building baths, and publicly declared it in his inscription, in order to demonstrate his intention of renouncing a typical symbol of secular power and instead embracing a symbol of pious patronage such as the erection of a church. ${ }^{50}$ Roman thermal baths were incorporated in the area of Arichis II's residence in Salerno and traces of a frigidarium and a balneum, dating later than the eighth century but within the eleventh century, have been uncovered. ${ }^{51}$

Let us consider the choice of Anastasius the Persian. Nothing in the Corteolona inscription explains the Lombard king's preference for this saint. For example, the fame of his relics in effecting miracles is not even hinted at. ${ }^{52}$ However, this was no fortuitous choice among the many saints venerated in Rome, which included those from the East who had been promoted by eastern communities between the seventh and the eighth centuries. ${ }^{53}$ First and

47 For the Greek text of this miracle (BHG 89), which bears a date corresponding to the year 713/4, see Flusin, Saint Anastase le Perse, vol. 1, 157-187, esp. 3, 168-169 and 6, 174-175 on the refusal of amulets. The account, like others, was then put into Latin, for which see Vircillo Franklin, Latin Dossier, 129-144. Smith, Cursing and Curing, 465469, comments on this miracle against the background of religious practices reflecting the varied ethnicity of Christians in eighth-century Rome.

48 The literature on baths, from Greek to post-Byzantine is vast; for an overview see Nielsen, Thermae et Balnea; for an update, see Fagan, Genesis; for the transition between the early and the middle Byzantine period, see Berger, Das Bad.

49 Epitaph of Bishop Damian of Pavia, ed. Strecker Rhytmi Langobardici, CXXXIV, 719-720; Everett, Literacy, 244245.

50 Badini, Concezione della regalità, 300 .

51 Peduto, Il gruzzolo, 34.

52 As noted by Vircillo Franklin, Latin Dossier, 18.

53 On eastern saints in Rome, see Sansterre, Les moines grecs, vol. 1, 146-156; for a recent appraisal of evidence and previous literature, see Maskarinec, City of Saints. 
foremost, Anastasius the Persian was a saint favoured by the Byzantine emperor Heraclius (610-641), who had defeated the Persians and brought back the True Cross to Jerusalem after they had taken it. The future Saint Anastasius was a soldier in the army of the Persian king Chosroes, who invaded Palestine in the early seventh century. After the fall of Jerusalem in 614, Anastasius developed an interest in the religion of the cross and later decided to be baptised and assumed a Christian name. He ardently embraced first the monastic life and then proselytism. Captured by Persians, he was beheaded in 628. Ten days later the victorious army of Heraclius arrived in the city of his martyrdom. Apparently, Anastasius soon became a symbol of a Christianity triumphant over paganism. ${ }^{54}$ By 630 his deeds were recounted in a text commissioned by Patriarch Modestus of Jerusalem. The return of his relics to Jerusalem from Persia by the late 631 was paralleled to Heraclius' restoration of the Cross which had been stolen by the Persians. ${ }^{55}$ Only a few years later, in the aftermath of the Arab invasion of Palestine of 638, the relics of Anastasius were taken by Palestinian monks to Rome..$^{56}$ There they found shelter at a monastery probably established by Cilician monks in the first half of the seventh century, which hence became one of the most important eastern monasteries of Rome with the name of Saint Anastasius ad aquas salvias. By the mid-seventh century it became the epicentre of the cult of Anastasius, since it hosted his relics and probably also the original hagiographical accounts on him. ${ }^{57}$ Not only was Anastasius associated with a rightful emperor Heraclius; according to Vircillo Franklin, the Persian martyr was associated very early with the defence of orthodoxy. ${ }^{58}$ She situates the early development of the cult of Anastasius in Rome within the monastic communities engaged against monotheletism, the doctrine of sone will of Christ, around the mid-seventh century, which could, in her eyes, rexplain the early link forged between the veneration of his relics and the defence of orthodoxy ${ }^{59}$ These eastern monks in fact supported Dyotheletism, the doctrine of Christ's human and divine swills', and labelled monotheletism as sheresy<, although it was a strand of Chalcedonian Christology ${ }^{60}$ Vircillo Franklin argues that the impression that the cult of Anastasius was associated with >orthodoxy - or, we should rather say, with its appropriation,- is reinforced when taking into account the acts of Nicaea II, where the Life of Anastasius is quoted in various instances, all related to iconophile practices. The first instance is to remark that Anastasius' conversion to Christianity when he was still a Persian soldier was inspired by stories of the martyrs (riotopías

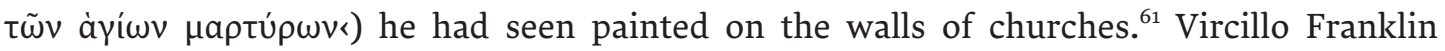

54 Vircillo Franklin, Latin Dossier, 3-4, with reference to Flusin, Saint Anastase le Perse, vol. 2, 329-352.

55 For a detailed and documented account of these facts, I refer to Vircillo Franklin, Latin Dossier, 5.

56 Vircillo Franklin, Latin Dossier, 11-12, notes that this remains conjectural. However, by 645 Anastasius was commemorated in Rome.

57 Vircillo Franklin, Latin Dossier, 8. The abundant Greek and Latin literature about Anastasius makes his cult perhaps the best documented among those of eastern saints in early medieval Rome.

58 Vircillo Franklin, Latin Dossier, 11 and 18 with reference to the Corteolona inscription.

59 Vircillo Franklin, Latin Dossier, 11.

60 See Jankowiak, Invention, 335, n. 1, for an updated bibliography on monotheletism. On the monothelete crisis and the Roman resistance, which culminated with the Lateran Synod of 649, see Price, Monotheletism, and Price et al., Acts, 14, 39-58; Booth, Crisis, 290-300.

61 Mansi, XIII, 21-22; ACO, II, 3.2, ed. Lamberz, 312-313; Vircillo Franklin, Latin Dossier, 7. 
specifically mentions Liutprand and it is therefore worth reporting what she writes: >Since Anastasius' status as a witness against iconoclasm is evident at Nicaea II, such a reputation may have already been established by the time of Liutprand's visit to Romer - a reputation which originated from the monastery's traditional alliance with the Church of Rome since the anti-monothelete resistance. ${ }^{62}$

\section{Appropriation of Rome?}

Liutprand's desire to forge for himself the image of a righteous and established ruler in the tradition of eminent predecessors can also be read in other features of the Corteolona texts. For example, in both main inscriptions there is an open reference to the appropriation of Roman-Christian remains (marbles, mosaics), ideally meant to be used in the material fabric of Liutprand's residence and certainly in his rhetoric of power. The appropriation and integration of spolia of former or other cultures is a vast subject which cannot even be summarised here. Importantly, it was a trait which characterised the rule of Constantine I, the first Roman emperor who accepted Christianity. He took possession of marbles carved for his predecessors or statues from pagan sanctuaries for monumental building projects which he carried out in Rome as well as in Constantinople, his new capital. ${ }^{63}$ Constantine set an example. Liutprand was ideally following in his steps, although on a much reduced scale, and this is what Charlemagne would also do.$^{64}$ In the first inscription, it is worth noting that the church at Corteolona, the shouse of the Lord<, is said to be made with sperpulchro ... textur, that is with a splendid fabric, made of marbles, mosaics, and columns provided by Rome, the scapital of the faith to the conclusion that, in Liutprand's eyes, since the fabric of the church was made of the fabric of Rome, it was permeated with its sanctity. The reference to splendid materials has both spiritual and material implications and is perfectly aligned with the late antique predilection for glittering materials and splendour which had become part of Christian aesthetics. ${ }^{65}$

A final element which deserves to be mentioned here, in that it has to do with the appropriation of traits of Roman imperial propaganda, is the reference in the first Corteolona inscription to the fact that Liutprand distributed inscriptions throughout the whole country. This passage conveys the idea that the Lombard king had embraced the practice of displaying script as a means of reminding people of his sovereignty. This practice had been embedded in the Roman imperial tradition of power since the age of Augustus, the first Roman emperor. ${ }^{66}$ While there is little left to witness the claim that Liutprand had commissioned many inscriptions, there is direct and indirect evidence of his sstrong involvement in epigraphic production<, certainly greater than any other Lombard king. ${ }^{67}$ This implies that Liutprand was aware that inscriptions were capable of transmitting messages and contributing to shaping his fame.

62 Vircillo Franklin, Latin Dossier, 18.

63 On the re-employment of ancient statues in Constantinople, see Bassett, Urban Image.

64 On the ideological re-employment of spolia, including a discussion of Charlemagne, see Brenk, Spolia; Kinney, Roman Architectural Spolia; Nelson, Charlemagne and Ravenna.

65 An evocative rhetoric of light is to be found in the inscriptions accompanying mosaics in Roman churches and it would be reprised by Carolingian poets. See Thunø, Decus suus splendet; idem, Inscription and divine presence; idem, Apse Mosaic; Dell'Acqua, Illuminando colorat. On the appropriation of Rome see Smith, Europe after Rome and Kramer and Gantner, Lateran Thinking.

66 Woolf, Monumental writing. Everett, Literacy, 253-254 on Liutprand.

67 Everett, Literacy, 250. 
The limited audience to which they were addressed was literate, and those who were learned could also read across the lines of the text and thus frame the sovereign's aspirations in a past in which Roman imperial power merged with Christian orthodoxy. That Liutprand did look back at the past for ideological reasons and with a learned approach is witnessed by the contents of one inscription that he, >devotus', commissioned in memory of the venerable Irish abbot Cumianus of Bobbio. ${ }^{68}$ The inscription, which runs in hexameters on the still extant tomb stone (Bobbio, Museo dell'Abbazia di San Colombano, Fig. 1), mentions sthe span of four Olympics` plus a year as a chronological reference to the twenty-one-year service of the abbot. Furthermore, the reference to the >dissolving limbs` of Cumianus has been retraced in Virgil (Aen. XII, 951), one of the most relevant poets of the Roman tradition. ${ }^{69}$ Although we cannot explore here how Liutprand's self-crafted image of a ruler had a bearing on later Lombard or Carolingian sovereigns, it is worth pointing out that after him the self-appointed Prince Arichis II in southern Langobardia also adopted elements of the Roman imperial culture and rhetoric in an effort to craft his own image as a legitimate and established ruler. ${ }^{70}$

\section{Other evidence of an early reception of the Image Controversy}

That there was a rising doctrinal problem with the Byzantine emperor - a problem with practical consequences for the Church - is witnessed not only by the Corteolona inscription, but by other testimonies, including the Liber Pontificalis, whose trustworthiness, however, has been questioned. The Liber Pontificalis is indeed a difficult source when it comes to the Image Controversy. As we have seen, this controversy was inserted into the Life of Pope Gregory II (d. 11 February 731). We have also seen that this must have happened at the time of his successor Gregory III (March 731-November 741). As mentioned earlier, the entry for Gregory II reached Bede in Northumbria in or before 735, since he managed to incorporate it into his Chronica maiora. ${ }^{11}$ We would suggest that the entry for Gregory II reached England in a form comparable to the older version of the Life that has come down to us. This cannot be proven since Bede did not include the latter parts of the text. Yet, the explanation that he had a partial, even older and therefore unfinished version of the Liber Pontificalis Life seems to be a far-fetched hypothesis. We can conclude that by the first half of the 730 s it was deemed acceptable in Rome to weave a theological controversy regarding images into a text that reflected the stax war the popes had had with the very same emperor in the previous decade. The adaptability of papal historical self-representation should not come as a surprise, because the tides of religious policy were shifting.

68 Epitaph of Abbot Cumianus, Rerum Italicarum Scriptores, ed. Muratori, vol. 3, 680; MGH, PLAK 4.2 ed. Strecker, 723: 'Hic sacra beati membra Cumiani solvuntur cuius caelum penetrans anima cum angelis gaudet. Iste fuit magnus dignitate genere forma hunc misit Scothia fines ad italicos senem locatur Ebovio domini constrictus amore ubi venerandi dogma Columbani servando vigilans ieiunans indefessus sidule orans olimpiadis quattuor uniusque circolo anni. Sic vixit feliciter ut felix modo credatur mitis prudens pius fratribus paceficus cunctis huic aetatis anni fuerunt novies deni. Lustrun quoque unum mensesque quattuor simul at pater egregie potens intercessor exsiste pro gloriosissimo Liutprando rege qui tuum praetioso lapide tymbum decoravit devotus sit ut manifestum almum ubi tegitur corpus depositus est hic dominus Cumianus Episcopus XIIII Kalendas Septembris‘; commented in Cassanelli, Materiali lapidei; Lomartire, L'iscrizione di Cumiano; see Calzona, Reimpiego e modelli, for an appraisal of earlier literature. See also Everett, Literacy, 251-253.

69 Cassanelli, Materiali lapidei, 513. In the English translation of Handley, Saxons, Britons and Scots, 749-750 the references to the Olympics and to Virgil have not been noted.

70 Dell'Acqua, Arechi II.

71 See Gantner, Freunde Roms 27, for details on the transmission. 


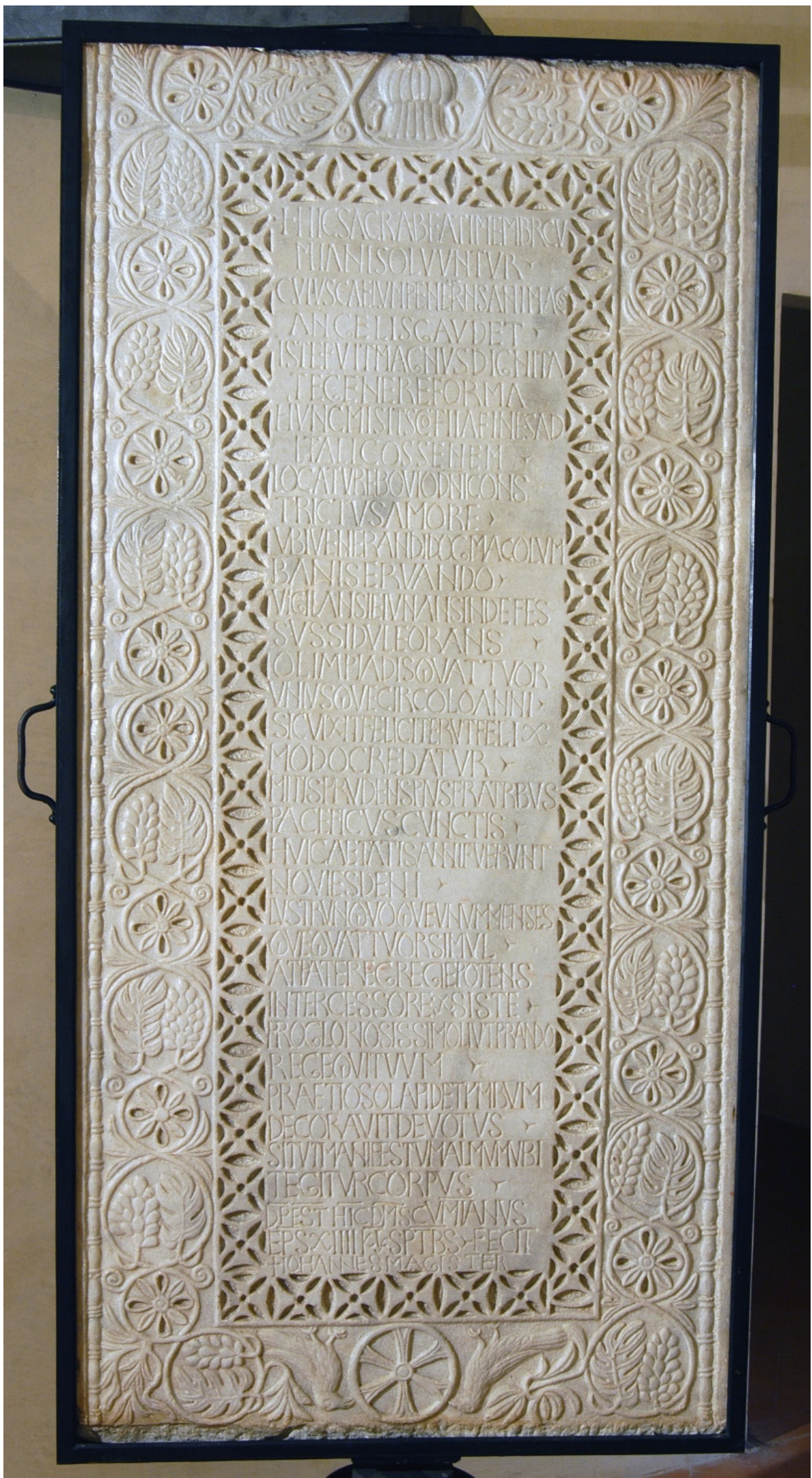

Fig. 1: Tombstone of Abbot Cumianus, c.736, marble, $180 \times 90 \mathrm{~cm}$, Bobbio (Piacenza), Museo dell'Abbazia di San Colombano 
The Life of Gregory III in the Liber Pontificalis informs us that in 731, shortly after his election as pope, he sent an embassy to Constantinople to address the question of sacred images. His envoys were carrying letters containing swritten warnings ( ‘commonitoria scripta`) against the removal and destruction of the sacred images of our Lord Jesus Christ, God's holy mother, the holy apostles and all the saints and confessors.$^{72}$ The same section of his Life claims that Gregory's predecessor (Gregory II) had already sent letters east concerning iconoclasm, clearly embracing the new papal narrative of the 720s, possibly elaborated within the same circles in the Lateran. The text also makes it clear that the diplomatic dispatch came to nothing, because one embassy lacked the courage to carry out their mission and the other was held up, detained and turned back towards Sicily instead. The next chapter in the same Life then reads:

So, spurred with a greater enthusiasm for the faith, the supreme and venerable pope [held] a sacerdotal synod in front of the most holy confessio of St Peter's most sacred body. With him in session were the archbishops Antoninus of Grado and John of Ravenna with other bishops of this Hesperian district, 93 in number and priests of this holy apostolic see; the deacons and all the clergy were in attendance, and the noble consuls and the rest of the Christian people assisted. The synod decreed that if anyone thenceforth, despising the faithful use of those who held the ancient custom of the apostolic church, should remove, destroy, profane and blaspheme against this veneration of the sacred images, viz. of our God and Lord Jesus Christ, of his mother the ever-virgin immaculate and glorious Mary, of the blessed apostles and of all the saints, let him be driven forth from the body and blood of our Lord Jesus Christ and from the unity and membership of the entire church. They also confirmed this by their signatures and sanctioned that it be attached to the other teachings of the previous approved orthodox pontiffs. ${ }^{73}$

Thus, in reaction to the first, luckless embassy, Gregory convened a synod in Rome, which is openly said to have threatened everyone holding riconoclast « views with excommunication. The problem is that we lack any secure dating for the Life of Gregory III. It is believed to have been written close to the events and finished during the tenure of Pope Zachary (741-752), yet manuscript evidence starts only in the late eighth century and we have no clear citations in other works far prior to that. ${ }^{74}$ The synod mentioned in the account was in all probability held starting on 1 November 731. Its acts are lost, however, with only the Liber Pontificalis as we have seen quite a partisan source - recounting the outcome.

We have, however, another source for the events of 731: the letter Gregory III sent to Patriarch Antoninus of Grado to convene him to the synod. Antoninus is then also mentioned as a participant of this synod in the Liber Pontificalis. The authenticity of this letter has been challenged, but on rather feeble grounds. ${ }^{75}$ The current version of the letter gives >Gregorius tertius as the author of the letter, which certainly is interpolated since the popes did not use ordinal numbers at this time. The letter itself, however, at least partly sounds authentic. ${ }^{76}$

LP, Gregory III, c. 2, trans. Davis, vol. 2, 19; ed. Duchesne, vol. 1, 415.

Gantner, Freunde Roms, 16-38. See also Davis, Lives of the Eighth-Century Popes, xvii-xx. See Speck, Kaiser Leon III, vol. 3, 586-87 and Conte, Regesto delle lettere dei papi, 200-201.

Regesta Pontificum Romanorum, vol. 2 (a. 604-844), ed. Jaffé, Könighaus, Schlauwitz, no. 3817 (olim JE 2232), 120, and ibid. nos. 3819 and 3820 (the latter indicating that the editors do not believe the account given in the LP, whereas they count the letter itself as authentic). 
The central accusation reads as follows: 'An unhappy impiety has arisen in the royal city [Constantinople], which - as we believe - you have noticed, and throughout many other provinces, so that, as we say lamenting and with a tearful voice, the holy images showing the likeness of our Lord himself and our saviour have all been scattered and [...] the churches of the same God [...] have been made into homes for men and for vile beasts.$^{77}$ The first part in particular is important here, because no one in Constantinople is clearly implicated yet. Later accounts always find Emperor Leo guilty - as we have seen for the Life of Gregory II, but there are other examples. We would argue that at least this part - where the pope speaks of an sinfelix impietas s that has arisen - is to be seen as genuine, while other parts of the text may have been altered to fit later perceptions. That this is the case is also backed up by the use of the expression rregia urbs ' which is typical of the time, whereas later forgeries tend to use the name Constantinople. ${ }^{78}$

Therefore, we can discern that at some point in 731 the pope was informed that the threat of a schism was again materialising in the East - a threat, which had dominated relations between Rome and Constantinople since the mid-seventh century. Gregory III was cautious enough not to blame anyone in particular for this development yet, at least not when writing to the patriarch of Grado. Instead, he chose a very vague expression, an sunhappy impiety, which is exactly what makes the text credible and authentic. The pope avoids including any personal charges against the emperor, while (possibly) giving a far more vivid and most likely exaggerated description of the general problems in the East. The Corteolona inscription, in contrast, clearly identifies the emperor as failing to rule in a religiously correct way.

Concerning images, Gregory III was quite outspoken, compared to the Liber Pontificalis and the Corteolona inscription. We can either count this latter part as spurious, or, more likely, as an attempt to plant the theme of resistance against the East into the heart of his addressee Antoninus. What the letter proves in any case is that there was some kind of hostility against images arising in Constantinople by 731 and that the western onlookers were swift to oppose it. ${ }^{79}$ The history of the relations teaches us that this was probably due to the papacy opposing teachings not previously negotiated.

77 Gregory III, Letter to Antoninus of Grado, ed. Gundlach: `Est enim infelix impietas apud regiam urbem, ut - credimus - notum habetis, et per diversas provincias, ita ut, quod lugentes dicimus et voce promimus lacrimosa, sanctorum imagines ad ipsius domini et redemptoris nostri instar omnes proiciantur, ecclesię delacerentur atque ipsius Dei ecclesiae, quod fatale malum est et intollerabile exitium, habitationes hominum, viliums utique efficiantur armentorum, ut iam in eis nulla debeat laus Deo cantari; unde cum profeta lamentabili voce dicendum est: Quis dabit capiti meo aquas aut oculis meis lacrimarum fontes, ut tantum defleamus exitum?

78 Gantner, Label Greeks, esp. 323. See discussion of interpolated letters of Gregory II in the same article.

79 See Brubaker and Haldon, Byzantium: A History, 119-120. 


\section{The afterlife of the Corteolona inscription}

It has been posited that the above-discussed Corteolona inscriptions were displayed in the monastery of Saint Anastasius annexed to Liutprand's residence, which also had a hospice for visitors. ${ }^{80}$ By the late eighth century, among the visitors or the permanent residents of Corteolona there must have been one who copied and thus transmitted these inscriptions and others from Pavia and its surroundings to posterity. They were then copied in a scriptorium in northeastern France. Between 821 and 835, the inscriptions were collated with others from Lombard Italy, Rome, and Ravenna at the monastery of Lorsch, forming the so-called Sylloge Laureshamensis (BAV, Pal. lat. 833, fols. 26r-82r). The Sylloge was either written at the monastery of Lorsch or transferred there promptly in the early ninth century. ${ }^{81}$ The collection seems to be a compilation of four separate collections, the first one possibly connected to a journey to Rome undertaken in 823 by Abbot Adalung of Lorsch (804-837). The texts from Lombard northern Italy, in the third section of the collection, likely stem from a different source, which was possibly produced at the end of the eighth century, judging from the latest inscriptions it includes, and was then copied into the Lorsch manuscript.

The varied nature of the inscriptions gathered suggests that they were transcribed to satisfy an antiquarian interest. However, we cannot entirely rule out the possibility that a political agenda dictated the collection of inscriptions related to the kingdom of Liutprand, which was already perceived in the late eighth century as the sgolden age of Lombard rule in Italy. At the same time, we cannot rule out scribal errors, since the inscriptions in the relevant section of the manuscript have come down to us in at least two steps. The Latin itself is not flawless. Since Carolingian epigraphy in the time of Charlemagne borrowed a lot from Lombard scholars summoned from Italy, we also cannot distinguish between a specific `Lombard or 'Carolingian s style.$^{82}$ The name form `Leutprand or >Leutbrant that is employed for the king himself in the two inscriptions from Corteolona, is, however, very clearly a Frankish rendering of the name. There is no sensible explanation other than that the copyist must have altered the name, which was probably used in an unfamiliar form, either in the Lombard language or in a Latinised hybrid that prompted the scorrection«. The most logical explanation would then be that the copyist of the extant manuscript transmitting the inscriptions (BAV, Pal. Lat. 833) or of the preceding collection from the late eight century was a Frank or at least must have lived in an area where Frankish versions of names were more common. It is clear, however, that the name form was deliberately chosen with a Frankish speaking audience in mind. We have shown in the previous section that this need not surprise us, as on Gregory III's letter the title of the pope was likewise adjusted by adding the ordinal number, making the letter meet the expectations of the audience it was copied for, in this case Italy during the

80 Everett, Literacy, 254.

81 The earliest testimony of the Sylloge is in the manuscript from Lorsch (BAV, Pal. lat. 833). The manuscript is easily accessible online: bibliotheca-laureshamensis-digital.de/bav/bav_pal_lat_833/0104 (retrieved 7 March 2019), second fascicle. The inscriptions from Pavia and surroundings form the third part of the Sylloge, and specifically those from Corteolona are to be found on fols. $48 \mathrm{v}-49 \mathrm{r}$, while the most relevant inscription for this article, the third copied, starts at the bottom of fol. 48v, after the second IITEM IBI rubric. On the manuscript, see Stevenson, Codices manuscripti, 292; Bischoff, Abtei Lorsch, 66 and 92, n. 47, 47a, 48, and idem, Lorsch, 114-115; for an appraisal and a critical overview on the Sylloge, see Vircillo Franklin, Epigraphic Syllogae, and more recently Hartmann, Karolingische Gelehrte.

82 See Hartmann, Karolingische Gelehrte, 259-263. 
Renaissance period. In sum, the name form `Leutprand/Leutbrant`, which cannot have been in the original inscription, proves that the text of the inscriptions was indeed altered, at least to render it more understandable for a Frankish audience, although we believe it highly unlikely that the content was significantly changed apart from the king's name. The metrics, for instance, were not tampered with and the grammar employed does not seem suspicious. ${ }^{83}$

There have been speculations as to who was responsible for collating the inscriptions. Dungal, a learned Irishman living in Pavia, has been proposed as a possible candidate. He is better known for having responded with a treatise to the iconoclastic Bishop Claudius of Turin in the 820s. ${ }^{84}$ But the date of Dungal's arrival in Pavia, in 825, makes it unlikely that he transcribed the inscriptions in the area of Pavia when considering, on the one hand, that the manuscript containing them arrived from northeast France to Lorsch between 821 and 835, as stated, and on the other, that the relevant part of the collection containing Corteolona was even older. ${ }^{85}$ In his stead, the name of another learned member of the Carolingian court has been put forward as a collector of ancient and Lombard antiquities: Angilbert of St Riquier, who resided in Pavia in $c .781 .{ }^{86}$ While the identity of the compiler of the part of the Sylloge including the inscriptions from Corteolona remains speculative and beyond the scope of this article, we can add a few comments on the reasons behind copying those texts from the Lombard country residence. A person connected with the Carolingians, if this was the case, would not have had any interest in praising Liutprand as a champion of faith. Instead, had the person been a Lombard, we can imagine they would have had a specific interest in extolling the memory of Liutprand as an orthodox ruler supportive of the popes, and thus probably amend the bad reputation he and his people acquired in papal and Frankish eyes and documents after they started threatening territories under papal control. ${ }^{87}$ It should be noted that the tone of the Corteolona inscriptions is echoed in the final book of the History of the Lombards, which Paul the Deacon wrote in the last decades of the eighth century ${ }^{88}$ Like the inscription set up in the Lombard royal residence, Paul portrays Liutprand as a spious king and contrasts him with the impious emperor Leo III. Probably relying on the Liber Pontificalis, as he does in other parts of the History of the Lombards, Paul blames the Byzantine sovereign for burning sacred images in Constantinople and for ordering the pope to dispose of sacred images if he wanted to retain imperial favour. Paul also reports that Leo obliged the citizens of Constantinople to take down images of the Saviour, his Mother, and all saints, which were burnt in the centre of the city, and those op-

83 For further thoughts on the nature of the inscriptions collected see Hartmann, Karolingische Gelehrte, 259-263.

84 Ferrari, In Papia. On the iconoclastic attitudes and exegetical work of Claudius of Turin, see Boulhol, Claude de Turin; Ballardini, Fare immagini. Against Claudius, in c.828 Dungal wrote the treatise Responsa contra Claudium, PL 105, 465-530, esp. 529; ed. and English trans. Zanna.

85 Vircillo Franklin, Epigraphic Syllogae, 985-986.

86 Vircillo Franklin, Epigraphic Syllogae, 986.

87 The popes labelled the Lombards as nefandissimi, that is most execrable. This would have a long-lasting effect on their image and even modern historiography; see Gasparri, Molteplici identità.

88 Goffart, Narrators, 340-341, for the debate on the date of the HL. 
posing this were either beheaded or mutilated. ${ }^{89}$ For his vision of the early period of the iconoclastic controversy, we can infer that, besides the Liber Pontificalis, Paul the Deacon was relying also on other sources, including the inscriptions from the royal residence of Corteolona, which were testimony to a more glorious period for the Lombards.

\section{Final remarks}

The inscriptions from Corteolona offer material for re-thinking a wide range of historical issues. We were only able to deal with some of them in this paper. For example, despite it being very important from a cultural-historical point of view, we had to leave aside the question of how the image of a pious Christian ruler, at the same time clad with symbols of Roman imperial power, that Liutprand construed for himself, eventually had an impact first on Arichis II and then on Charlemagne. We intended, in fact, to focus on the mention of Emperor Leo III in the longer inscription from Corteolona. But in the end, what has our investigation found out? First of all, we have come to the conclusion that the texts of the Corteolona inscriptions transmitted to us in the Sylloge Laureshamensis, a collection mainly following antiquarian interests, must be genuine. No one would have had an interest in interpolating a statement about the foundation of a church and a monastery of Saint Anastasius at Corteolona.

The dating of the inscription is admittedly less secure, with 729, the year Liutprand enters Rome, as a certain terminus post quem. There is no other documentary evidence about the establishment of the country residence of Liutprand, nor archaeological investigations about it. However, we have argued that a date between 730 and 734 for the inscription is by far the most convincing. In fact, the wording itself fits quite well in the then current political discourse. Liutprand wants to depict himself as more pious than Leo III, but he clearly avoids all too concrete allegations against the emperor.

The existence of the inscription indicates that it was already clear enough to well-informed onlookers in Italy that the emperor was indeed involved in the establishment of a new religious policy and that this new religious policy was deemed schismatic (possibly heretical) by several Italian churches (the Lombard, but also the Roman church). All the same, the inscription does not inform us what the schism was about, since it only conveys that Liutprand defined himself as true orthodox and Catholic in contrast to his eastern, higher ranking counterpart. By humiliating the great emperor, who had gained fame as a Christian hero against the Umayyad Empire, Liutprand exalted himself, and that certainly was the main goal of the first two lines of the poem. The author of the verse inscription, however, finds a way to shift part of the blame away from the emperor and put it instead on a nameless doctor.

The value of this specific inscription from Corteolona resides in the fact it conveys information that we do not have from any other contemporary source, mainly that the threat of a schism originating in Byzantium was perceived, resented, and condemned in Lombard territories at quite an early stage and that it was related to the emperor himself. That the rising image controversy is indeed implied in the text by the words about Leo's fall sinto the pit of schism < becomes clear from the Liber Pontificalis and from the letter from Gregory III to Antoninus of Grado, as well as, to a certain extent, from Greek sources from the core lands

89 Paul the Deacon, HL, VI, 49, ed. Dümmler, 181-182. 
of the empire in Asia minor. ${ }^{90}$ We have come to the conclusion that these different sources cannot all have been forged with a concerted effort aimed at pre-dating iconoclasm, as was postulated not too long ago. ${ }^{91}$ It now appears clear that several circles in Italy, namely in Rome and in northern Langobardia, reacted quite early to the controversy rising in the East, certainly by the early months of the year 731. In the same year, or shortly thereafter, scribes in the Lateran decided to alter the narrative of Gregory II's struggles against the emperor when presenting them in the Liber Pontificalis, making them, too, about images. In these years, independently from the pope, Liutprand decided to contrast the schismatic attitude of the emperor with the decision to establish a church and a monastery dedicated to an eastern saint associated with Byzantine imperial power in his new residential complex instead of luxurious baths.

As said previously, the inscription from Corteolona has, quite surprisingly, not been taken into account as a source for the emerging image controversy, nor for the early reactions against it in Italy. Albeit succinct, the inscription provides the missing piece to back up other sources and shows that the latter also represent a genuine and early reaction to Byzantine iconoclasm. With information having very different and unrelated origins, but dovetailing neatly all the same, we can see that the early 730 s were indeed the first hot phase of the image controversy in Italy.

90 See Brubaker and Haldon, Byzantium: The Sources, 69-155.

91 Speck, Kaiser Leon III. 


\section{Acknowledgements}

This research started during a Marie Skłodowska-Curie Fellowship ( $\mathrm{n}^{\circ}$ 657240, 'ICONOPHILIA') spent at the Centre for Byzantine, Ottoman and Modern Greek Studies, School of History and Cultures, College of Arts and Law, University of Birmingham.

It has been partly financed and facilitated by the participation of Francesca Dell'Acqua in the project `Mobility, Microstructures and Personal Agency in Byzantium` (2015 Wittgenstein-Prize of the Austrian National Research Foundation) directed by Prof. Dr. Claudia Rapp at the University of Vienna and the Austrian Academy of Sciences. The authors are grateful to Marc Lauxtermann, Oxford, for generously sharing his still unpublished paper dealing with the longer Corteolona inscription. Dell'Acqua wishes to thank the participants to the medieval seminar group of the Austrian Academy of Sciences, Vienna, with whom she first discussed the inscription from Corteolona in March 2018 and where the idea for this joint article came about. She also wishes to thank warmly Adriano Peroni, Saverio Lomartire, and Caterina Giostra for useful information on the site of Corteolona and the inscriptions from Pavia. Clemens Gantner wishes to thank Cinzia Grifoni, Christian Gastgeber, Bernhard Zeller, and Walter Pohl for fruitful discussions on the topics addressed here. 


\title{
References
}

\author{
Abbreviations \\ ACO = Acta Conciliorum Oecumenicorum \\ $\mathrm{BAV}=$ Biblioteca Apostolica Vaticana \\ BHG = Bibliotheca Hagiographica Graeca \\ $\mathrm{HL}=$ Historia Langobardorum \\ LP $=$ Liber Pontificalis \\ MGH EE = Monumenta Germaniae Historica, Epistolae \\ MGH, PLAK = Monumenta Germaniae Historica, Poetae Latini Aevi Karolini \\ MGH, SRL = Monumenta Germaniae Historica, Scriptores Rerum Langobardicarum et Ital- \\ icarum saec. VI-IX \\ PG = Patrologiae Cursus Completus, Series Graeca, ed. Jacques-Paul Migne (Paris, 1857- \\ 1866). \\ $\mathrm{PL}=$ Patrologiae Cursus Completus, Series Latina, ed. Jacques-Paul Migne (Paris, 1844-1890).
}

ACO II, 2.2 = Concilium Universale Constantinopolitanum Tertium, Concilii Actiones XIIXVIII, ed. Rudolf Riedinger, ACO, II, 2.2 (Berlin, 1992).

ACO II, 3.1 = Concilium Universale Nicaenum Secundum, Concilii actiones I-III, ed. Erich Lamberz, ACO, II, 3.1 (Berlin, 2008).

ACO II, 3.2 = Concilium Universale Nicaenum Secundum, Concilii Actiones IV-V, ed. Erich Lamberz, ACO, II, 3.2 (Berlin, 2012).

Badini, Aldo, La concezione della regalità in Liutprando e le iscrizioni della chiesa di S. Anastasio a Corteolona, in: Atti del VI Congresso internazionale di studi sull'Alto Medioevo. Milano, 21-25 ottobre 1978 (Spoleto, 1980) 283-302.

Ballardini, Antonella, Fare immagini tra Occidente e Oriente: Claudio di Torino, Pasquale I e leone V l'Armeno, in: Arturo Carlo Quintavalle (ed.), Medioevo mediterraneo: l'Occidente, Bisanzio e l'Islam, I convegni di Parma 7 (Milan, 2007) 194-214.

BAV, Pal. lat. 833 = Rome, Biblioteca Apostolica Vaticana, Palatinus Latinus 833. Retrieved 7 March 2019: bibliotheca-laureshamensis-digital.de/bav/bav_pal_lat_833/0104.

Bassett, Sarah, The Urban Image of Late Antique Constantinople (Cambridge, 2004).

Berger, Albrecht, Das Bad in der byzantinischen Zeit, Miscellanea Byzantina Monacensia 27 (Munich, 1982).

Berto, Luigi A., Liutprando, re dei Longobardi, in: Dizionario biografico degli Italiani 65 (2005). Retrieved 28 January 2019: www.treccani.it/enciclopedia/re-dei-longobardiliutprando_(Dizionario-Biografico).

Bertolini, Ottorino, Roma e i Longobardi (Rome, 1972).

Bertolini, Ottorino, and Cinzio Violante, Storia Universale 3.1. I Germani, migrazioni e regni nell'Occidente già romano, i Franchi (Milan, 1965).

Bischoff, Bernhard, Lorsch im Spiegel seiner Handschriften, Münchener Beiträge zur Mediävistik und Renaissance-Forschung 2 (Munich, 1974).

Bischoff, Bernhard, Die Abtei Lorsch im Spiegel ihrer Handschriften, Geschichtsblätter Kreis Bergstraße. Sonderband 10 (second expanded edition), (Lorsch 1989).

Booth, Philip, Crisis of Empire: Doctrine and Dissent at the End of Late Antiquity (Berkeley, London, 2014). 
Boulhol, Pascal, Claude de Turin: un évêque iconoclaste dans l'Occident Carolingien: Étude suivie de l'édition du Commentaire sur Josué, Collection des études augustiniennes, Série Moyen-âge et Temps Modernes 38 (Paris, 2002).

Brandes, Wolfram, Finanzverwaltung in Krisenzeiten: Untersuchungen zur byzantinischen Administration im 6.-9. Jahrhundert, Forschungen zur byzantinischen Rechtsgeschichte 25 (Frankfurt am Main, 2002).

Brenk, Beat, Spolia from Constantine to Charlemagne: Aesthetics versus ideology, Dumbarton Oaks Papers 41 (1987) 103-109.

Brubaker, Leslie, and Haldon, John F., Byzantium in the Iconoclast Era, c. 680-850: A History (Cambridge, 2011).

Brubaker, Leslie, and Haldon, John F., Byzantium in the Iconoclast Era (ca.680-850): The Sources, an Annotated Survey. Birmingham Byzantine and Ottoman Studies 7 (Aldershot, 2001).

Calderini, Caterina, Il palazzo di Liutprando a Corteolona, Contributi dell'Istituto di Archeologia 5 (1975) 174-208.

Calzona, Arturo, Reimpiego e modelli tra VIII e IX secolo al San Colombano di Bobbio, in: Arturo Carlo Quintavalle (ed.), Medioevo: $i$ modelli. Atti del convegno internazionale di studi, Parma 27 settembre-1 ottobre 1999, I convegni di Parma 2 (Milano, 2002) 291-308.

Cassanelli, Roberto, Materiali lapidei altomedievali decorati e iscritti nell'abbazia di San Colombano a Bobbio, in: Mirella Marini Calvani (ed.), Storia di Piacenza, vol. I: Dalle origini all'anno Mille (Piacenza, 1990) 503-533.

Conte, Pietro, Regesto delle lettere dei papi del secolo VIII (Milan, 1984).

Cornford, Benjamin, Paul the Deacon's understanding of identity, his attitude to barbarians, and his sstrategies of distinction in the Historia Romana, in: Richard Corradini, Rob Meens, Christina Pössel and Philip Shaw (eds.), Texts and Identities in the Early Middle Ages (Vienna, 2006) 47-60.

Dell'Acqua, Francesca, Arechi II: la promozione artistica come tratto reroicor?, in: Gabriella D'Henry and Chiara Lambert (eds.), Il popolo dei Longobardi meridionali (570-1076), Atti del convegno (Salerno, 2009) 75-92.

Dell'Acqua, Francesca, Illuminando colorat. La vetrata tra la tarda Antichità e l'alto Medioevo attraverso le fonti e l'archeologia, Studi e Ricerche di Archeologia e Storia dell'Arte 4 (Spoleto, 2003).

Dungal, Responsa contra Claudium. A Controversy on Holy Images, ed. and trans. Paolo Zanna (Florence, 2002); PL 105, 465-530.

Epitaph of Abbot Cumianus, ed. Muratori, Rerum Italicarum Scriptores, t. III, 680; ed. Dümmler, MGH, PLAK 4.2, ed. Karl Strecker (Berlin, 1923) 723.

Epitaph of Bishop Damian of Pavia, ed. Karl Strecker, Rhytmi Langobardici, CXXXIV, MGH, PLAK 4.2 (Berlin, 1923) 719-720.

Everett, Nicholas, Literacy in Lombard Italy, c. 568-774, Cambridge Studies in Medieval Life and Thought 53 (Cambridge, 2003).

Fagan, Garrett G., The Genesis of the Roman Public Bath: Recent Approaches and Future Directions, American Journal of Archaeology 105/3 (2001) 403-426.

Falla Castelfranchi, Marina, Arechi II e Giustiniano, in: Arturo Carlo Quintavalle (ed.), Medioevo. Immagini e ideologie. I convegni di Parma 5 (Milan, 2008) 83-89. 
Fentress, Elizabeth, Katherine Gruspier, and Vera von Falkenhausen, The Sixth-Century Settlement, in: Elizabeth Fentress, John Bodel, T. V. Buttrey, Stefano Camaiani, Fernanda Cavari, Laura Cerri, Enrico Cirelli, Sergio Fontana, Elisabetta Gliozzo, Katherine Gruspier, Elisa Gusberti, Michelle Hobart, Valentina Lolini, Francesca Lunghetti, Alex Moseley, Silvia Nerucci, Adam Rabinowitz, Alessia Rovelli, Rabun Taylor, C. J. Simpson and Vera von Falkenhausen (eds.), Cosa V: An Intermittent Town, Excavations 1991-1997 (Ann Arbor MI, 2003), 72-91.

Ferrari, Mirella, In Papia conveniant ad Dungalum, Italia Medievale e Umanistica 15 (1972) 1-52. Flusin, Bernard, Saint Anastase le Perse et l'histoire de la Palestine au début du VIIe siècle, 2 vols, Le monde byzantin (Paris, 1992).

Gantner, Clemens, The label "Greeks« in the papal diplomatic repertoire in the eighth century, in: Walter Pohl and Gerda Heydemann (eds.), Strategies of Identification: ethnicity and religion in early medieval Europe (Turnhout, 2013) 303-349.

Gantner, Clemens, Freunde Roms und Völker der Finsternis. Die päpstliche Konstruktion von Anderen im 8. und 9. Jahrhundert (Vienna 2014).

Gasparri, Stefano, Le molteplici identità etniche dei Longobardi in Italia. Linguaggi politici e pratiche sociali, Mitteilungen des Deutschen Archäologischen Instituts. Römische Abteilung 118 (2012) 493-504.

Giorgi, Ignazio, Il Regesto del monastero di S. Anastasio ad Aquas Salvias, Archivio della Società Romana di storia patria 1 (1877-1878) 49-77.

Goffart, Walter, The Narrators of Barbarian History (A.D. 550-80o): Jordanes, Gregory of Tours, Bede, and Paul the Deacon (Princeton NJ, 1988).

Gregory III, Letter to Antoninus of Grado, ed. Wilhelm Gundlach, MGH EE 3, Epistolae langobardicae collectae 13 (Berlin, 1892) 703.

Hallenbeck, Jan T., Pavia and Rome: The Lombard monarchy and the papacy in the eighth century, Transactions of the American Philosophical Society 72/4 (1982) 1-186.

Handley, Mark A., Saxons, Britons and Scots: pilgrims, travellers and exiles on the continent, in: Lesley Webster and Andrew Reynolds (eds.), Early Medieval Art and Archaeology in the Northern World. Studies in Honour of James Graham-Campbell (Leiden, 2013) 743-778.

Hartmann, Florian, Karolingische Gelehrte als Dichter und der Wissenstransfer am Beispiel der Epigraphik, in: Julia Becker, Tino Licht and Stefan Weinfurter (eds.), Karolingische Klöster. Wissenstransfer und kulturelle Innovation, Materiale Textkulturen 4 (Berlin, München, Boston, 2015) 255-274.

Jankowiak, Marek, The Invention of Dyotheletism, Studia Patristica 63 (2013) 335-342.

Kinney, Dale, Roman Architectural Spolia, Proceedings of the American Philosophical Society 145/2 (2001) 138-161.

Kramer, Rutger and Gantner, Clemens, Lateran thinking: Building an idea of Rome in the Carolingian Empire, Viator 47 (2016) 1-26.

Lamberz, Erich, "Falsata Graecorum more«? Die griechische Version der Briefe Papst Hadrians I. in den Akten des VII. Ökumenischen Konzils, in: Claudia Sode and Sarolta Takács (eds.), Novum Millennium. Studies on Byzantine History and Culture Dedicated to Paul Speck (Aldershot, 2001) 213-229.

Lauxtermann, Marc D., A Lombard epigram in Greek, in: Marc D. Lauxtermann and Ida Toth (eds.), Inscribing Texts in Byzantium: Continuities and Transformations (London, 2019).

Laws of Liutprand = Leges Langobardorum, ed. Georg Heinrich Pertz, MGH, Leges 4 (Hanover, 1868) 96-182; trans. Katherine Fischer Drew, The Lombard Laws, Sources of Medieval History (Philadelphia PA, 1973). 
Liber Pontificalis, ed. Louis Duchesne, Le Liber Pontificalis: Texte, introduction et commentaire, 3 vols [vol. 3: Additions et corrections de Mgr L. Duchesne, ed. Cyrille Vogel] Paris 1955-1957); vol. 1: trans. Raymond Davis, The Book of Pontiffs (Liber Pontificalis): The Ancient Biographies of the First Ninety Roman Bishops to AD 715, Translated Texts for Historians 6 (Liverpool, 2000); vol. 2: trans. Raymond Davis, The Lives of the EighthCentury Popes (Liber Pontificalis): The Ancient Biographies of Nine Popes from AD 715 to $A D$ 817, Translated Texts for Historians 13 (Liverpool, 1992); vol. 3: trans. Raymond Davis, The Lives of the Ninth-Century Popes (Liber Pontificalis): The Ancient Biographies of Ten Popes from AD 817 to AD 891, Translated Texts for Historians 20 (Liverpool, 1995). Lomartire, Saverio, L'iscrizione di Cumiano e l'epigrafia longobarda dell'età liutprandea, in: Flavio G. Nuvolone (ed.), La fondazione di Bobbio nello sviluppo delle comunicazioni tra Langobardia e Toscana nel Medioevo. Atti del Convegno Internazionale Bobbio, Auditorium di S. Chiara, 1-2 Ottobre 1999, Archivum Bobiense Studia III (Bobbio, 2000) 57-70.

Lopez-Jantzen, Nicole, Kings of all Italy? Overlooking political and cultural boundaries in Lombard Italy, Medieval Perspectives 29 (2014) 75-91.

Macrides, Ruth, and Magdalino, Paul, The Architecture of ekphrasis: Construction and Context of Paul the Silentiary's Poem on Hagia Sophia, Byzantine and Modern Greek Studies 12 (1988) 47-82.

Mansi, Giovanni Domenico (ed.), Sacrorum conciliorum nova, et amplissima collectio, 53 vols (Florence, 1692-1769).

Maskarinec, Maya, City of Saints. Rebuilding Rome in the Early Middle Ages, Middle Ages Series (Philadelphia PA, 2018).

Muratori, Ludovico Antonio, ed., Rerum Italicarum Scriptores, vol. 3 (Milan, 1723).

Nelson, Jinty, Charlemagne and Ravenna, in: Jinty Nelson and Judith Herrin (eds.), Ravenna: Its role in Earlier Medieval Change and Exchange (London, 2016) 239-252.

Nielsen, Inge, Thermae et Balnea: The Architecture and Cultural History of Roman Public Baths, 2 vols. (Aarhus, 1993).

Noble, Thomas F.X., Images, Iconoclasm, and the Carolingians, The Middle Ages Series (Philadelphia, 2009).

Noble, Thomas F.X., The Republic of St. Peter (Philadelphia, 1984).

Paul the Deacon, Historia Langobardorum, ed. Georg Waitz, MGH, SRL (Hanover, 1878) 12-187.

Paul the Deacon, Versus de Arichi duce, VI-VII, ed. Ernst Dümmler, MGH, PLAK 1 (Berlin, 1881) 44-45.

Peduto, Paolo, Il gruzzolo del S. Salvatore de fondaco a Salerno: follari, tari, denari del secolo XI, Rassegna storica salernitana 16.8 (1991) 33-71.

Pohl, Walter, Das Papsttum und die Langobarden, in: Matthias Becher and Jörg Jarnut (eds.), Der Dynastiewechsel von 751. Vorgeschichte, Legitimationsstrategien und Erinnerung (Münster 2004) 145-161.

Pohl, Walter, Creating cultural resources for Carolingian rule: Historians of the Christian Empire, in: Clemens Gantner, Rosamond McKitterick and Sven Meeder (eds.), The Resources of the Past in Early Medieval Europe (Cambridge, 2015) 15-33.

Pohl, Walter, Legal Pluralism in Lombard Italy, in: Helmut Reimitz (ed.), Legal Pluralism and Social Change in Late Antiquity and the Early Middle Ages: Essays in Honor of John Haldon (forthcoming).

Price, Richard, Monotheletism: A heresy or a form of words?, Studia Patristica 48 (2010) 221-232.

Price, Richard, Philip Booth, and Catherine Cubitt, The Acts of the Lateran Synod of 649, Translated Texts for Historians 61 (Liverpool, 2014). 
PmbZ = Ralph-Johannes Lilie, Claudia Ludwig and Beate Zielke, Prosopographie der mittelbyzantinischen Zeit (Berlin, 2013). PmbZ online accessed on 19 February 2019: www. degruyter.com/view/db/pmbz.

Regesta Pontificum Romanorum, vol. 2 (a. 604-844), ed. Philipp Jaffé, Waldemar Könighaus, Thorsten Schlauwitz (Göttingen 2017).

Riccardi, Alessandro, Le vicende, l'area e gli avanzi del regium palatium e della cappella e monastero di S. Anastasio (Milan, 1889).

Sansterre, Jean-Marie., Les moines grecs et orientaux à Rome aux époques byzantine et carolingienne (milieu du VIe s.-fin du IXe s.), 2 vols. (Brussels, 1983).

Smith, Julia M.H., Europe after Rome: A New Cultural History, 500-10oo (Oxford: Oxford University Press, 2005).

Smith, Julia M.H., Cursing and Curing, or the Practice of Christianity in Eighth-Century Rome, in: Ross Balzaretti, Julia Barrow and Patricia Skinner (eds.), Italy and Early Medieval Europe: Papers for Chris Wickham, The Past and Present Book Series (Oxford, 2018) 460-475.

Sotinel, Claire, Das Dilemma des Westens: Der Drei-Kapitel-Streit, in: Luce Pietri (ed.), Geschichte des Christentums, Altertum, vol. 3: Der lateinische Westen und der byzantinische Osten (Freiburg 2005) 462-490.

Speck, Paul, Ich bin's nicht, Kaiser Konstantin ist es gewesen. Die Legenden vom Einfluss des

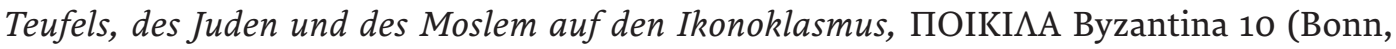
1990).

Speck, Paul, Kaiser Leon III., die Geschichtswerke des Nikephoros und des Theophanes und der Liber Pontificalis: Eine quellenkritische Untersuchung, Poikila Byzantina 20 (Bonn, 2003).

Stevenson, Henry M., Codices manuscripti Palatini graeci Bibliothecae Vaticanae, Bibliothecae Apostolicae Vaticanae codices manuscripti (Rome, 1886).

Thunø, Erik, Decus suus splendet ceu Phoebus in orbe. Zum Verhältnis von Text und Bild in der Apsis von Santa Maria in Domnica in Rom, in: Bernd Janowski and Nino Zchomelidse (eds.), Die Sichtbarkeit des Unsichtbaren, Arbeiten zur Geschichte und Wirkung der Bibel 3 (Tübingen, 2003) 147-164.

Thunø, Erik, Inscription and divine presence: Golden letters in the early medieval apse mosaic, Word \& Image 27/3 (2011) 279-291.

Thunø, Erik, The Apse Mosaic in Early Medieval Rome. Time, Network, and Repetition (New York, 2015).

Versus xii, In Ecclesia Beati Anastasi, MGH, PLAK 1, ed. Ernst Dümmler (Berlin, 1881) 106.

Vircillo Franklin, Carmela, The Epigraphic Syllogae of BAV, Palatinus Latinus 833, in: Jaqueline Hamesse (ed.), Roma, magistra mundi. Itineraria culturae medievalis. Mélanges offert au Père L.E. Boyle à l'occasion de son 75e anniversaire (Leuven, 1998) 975-990.

Vircillo Franklin, Carmela, The Latin Dossier of Anastasius the Persian. Hagiographic Translations and Transformations, Studies and Texts 147 (Toronto, 2004).

Woolf, Greg, Monumental writing and the expansion of Roman society in the early empire, The Journal of Roman Studies 86 (1996) 22-39.

\section{List of figures}

Figure 1: Tombstone of Abbot Cumianus, c.736, marble, 180 x $90 \mathrm{~cm}$, Bobbio (Piacenza), Museo dell'Abbazia di San Colombano @Ufficio per i Beni Culturali Ecclesiastici della Diocesi di Piacenza-Bobbio 